\title{
High Resolution Melting (HRM) applied to wine authenticity
}

\author{
Leonor Pereira $^{a, b, 1}$, Sónia Gomes ${ }^{\mathrm{a}, \mathrm{b}, 1}$, Cláudia Castro ${ }^{\mathrm{a}, \mathrm{b}}$, José Eduardo Eiras-Dias ${ }^{\mathrm{c}}$, João Brazão ${ }^{\mathrm{c}}$, \\ António Graça ${ }^{\mathrm{d}}$, José R. Fernandes ${ }^{\mathrm{a}, \mathrm{e}}$, Paula Martins-Lopes ${ }^{\mathrm{a}, \mathrm{b}, *}$ \\ ${ }^{a}$ University of Trás-os-Montes and Alto Douro, P.O. Box 1013, 5000-911 Vila Real, Portugal \\ ${ }^{\mathrm{b}}$ University of Lisboa, Faculty of Sciences, BioISI - Biosystems E Integrative Sciences Institute, Campo Grande, 1749-016 Lisboa, Portugal \\ ${ }^{\mathrm{c}}$ National Institute for Agricultural and Veterinary Research (INIAV), 2565-191 Dois Portos, Portugal \\ ' SOGRAPE VINHOS S.A., 4430-809 Avintes, Portugal \\ e INESC/TEC, Rua do Campo Alegre n. 687, 4169-007 Porto, Portugal
}

\section{A R T I C L E I N F O}

\section{Article history:}

Received 5 April 2016

Received in revised form 29 July 2016

Accepted 31 July 2016

Available online 1 August 2016

\section{Keywords}

Vitis vinifera $\mathrm{L}$.

Must

Wine

HRM

Authenticity

\begin{abstract}
A B S T R A C T
Wine authenticity methods are in increasing demand mainly in Denomination of Origin designations. The DNA-based methodologies are a reliable means of tracking food/wine varietal composition. The main aim of this work was the study of High Resolution Melting (HRM) application as a screening method for must and wine authenticity. Three sample types (leaf, must and wine) were used to validate the three developed HRM assays ( $V v 1-705 \mathrm{bp} ; V v 2-375 \mathrm{bp}$; and $V v 3-119 \mathrm{bp}$ ). The $V v 1$ HRM assay was only successful when applied to leaf and must samples. The $V v 2$ HRM assay successfully amplified all sample types, allowing genotype discrimination based on melting temperature values. The smallest amplicon, $V v 3$, produced a coincident melting curve shape in all sample types (leaf and wine) with corresponding genotypes. This study presents sensitive, rapid and efficient HRM assays applied for the first time to wine samples suitable for wine authenticity purposes.
\end{abstract}

๑) 2016 Elsevier Ltd. All rights reserved.

\section{Introduction}

It is estimated that about 10,000 different Vitis vinifera L. varieties exist worldwide (Gallet, 2000). However, only a few are used in wine production. When considering high valuable wines and the wines belonging to Denomination of Origin (DO), the number of varieties with interest is even lower.

Portugal is characterized by having a huge $V$. vinifera germplasm collection, with hundreds of varieties (Cunha, TeixeiraSantos, Brazão, Fevereiro, \& Eiras-Dias, 2013). In 1756, the regulation defining the Port Wine's region was established, being the first Demarcated region in the World (Região Demarcada do Douro). In 2001, the Douro region was classified by UNESCO as a world heritage site. In this region premier wines are produced mainly due to the grapevine varieties used and its terroir. In the Douro region there are old vineyards with a wide number of grapevine varieties, which are contrasting with the modern vineyards that have defined grapevine varieties used to produce monovarietal wines with high commercial value.

\footnotetext{
* Corresponding author at: University of Trás-os-Montes and Alto Douro, P.O. Box 1013, 5000-911 Vila Real, Portugal.

E-mail address: plopes@utad.pt (P. Martins-Lopes).

1 Equal contribution.
}

Governmental bodies have an obligation to control, promote and defend the DO appellations. In monovarietal wines the occasional addition of other grapevine varieties, above the percentage permitted by law, can occur and are considered illegal, unless stated, under labelling legislation (European Union Regulation $\mathrm{n}^{\circ}$ 607/2009). Thus, wine authenticity has become a subject of great concern since the incorrect labelling represents a commercial fraud. Therefore, the precise identification of the grapevine varietal composition is a key point to combat fraudulent practices and to assure commercial fairness.

Traditional methods used for must and wine grapevine varietal identification and authentication rely on protein and metabolites analysis and on the isotope ratios of certain bio-elements (Arbulu, Sampedro, Gómez-Caballero, Goicolea, \& Barrio, 2015; Camin et al., 2013; Sen \& Tokatli, 2014; Versari, Laurie, Ricci, Laghi, \& Parpinello, 2014). However, these analytical techniques are influenced by winemaking processes, environment and storage conditions (Arbulu et al., 2015), therefore leading to inconsistencies related to the accurate and reliable identification of grapevine varieties (Fang et al., 2008). DNA based methods are considered to be more reliable based on the fact that DNA is a stable molecule. Furthermore, DNA has been applied to several food matrices with remarkable success considering authenticity purposes (Faria, Magalhães, Nunes, \& Oliveira, 2013; Madesis, Ganopoulos, 
Sakaridis, Argiriou, \& Tsaftaris, 2014; Martins-Lopes, Gomes, Pereira, \& Guedes-Pinto, 2013).

Grapevine varietal identification is easily guaranteed with the use of nuclear molecular markers, namely, Simple Sequence Repeat (SSR) approved and supported by the International Organization of Vine and Wine (OIV; OIV, 2007). Although SSR markers have been used for food authenticity purposes several problems have arisen related to the DNA quality, a result of the extraction procedures (reviewed by Pereira, Gomes, \& Martins-Lopes, 2016). When considering must/wine matrices the presence of large quantities of polyphenols, polysaccharides and proteins sometimes inhibit PCR reactions (Işçi, Yildirim, \& Altindisli, 2014). Another drawback in the application of SSR markers, in such sample type, is related with DNA degradation, result of alcoholic fermentation process. However, several DNA extraction protocols have been improved and have managed to increase both the yield and the quality of the extracted DNA (e.g., Baleiras-Couto \& Eiras-Dias, 2006; Bigliazzi, Scali, Paolucci, Cresti, \& Vignani, 2012; Boccacci, Akkak, Marinoni, Gerbi, \& Schneider, 2012; Nakamura, Haraguchi, Mitani, \& Ohtsubo, 2007; Pereira, Guedes-Pinto, \& Martins-Lopes, 2011; Savazzini \& Martinelli, 2006). The use of small molecular markers, such as, Single Nucleotide Polymorphisms (SNPs) could be a way to overcome the natural DNA degradation found in such samples.

SNPs are considered the newest type of molecular markers that offer several advantages since they are abundant in the genome, genetically stable and can be used to overcome the degradation limitations allowing DNA amplification and the use of more sensitive techniques (Cabezas et al., 2011). High Resolution Melting (HRM) analysis has been widely used for mutation detection and genotyping. Due to its nature, it can be considered as an alternative approach for food authenticity purposes (Ganopoulos, Argiriou, \& Tsaftaris, 2011a; Ganopoulos, Argiriou, \& Tsaftaris, 2011b; Ganopoulos, Bazakos, Madesis, Kalaitzis, \& Tsaftaris, 2013a; Ganopoulos, Sakaridis, Argiriou, Madesis, \& Tsaftaris, 2013b; Madesis et al., 2014; Wittwer, 2009).

HRM analysis is a sensitive, stable, and reliable screening method that allows the rapid analysis of specific amplicons, characteristic of a particular genotype, previously amplified by PCR. In Vitis, HRM was applied in grapevine variety identification using various microsatellites (Mackay, Wright, \& Bonfiglioli, 2008). Recently, HRM has been applied by our group to the identification of grapevine varieties based on the SNPs changes detected within genes belonging to the anthocyanins pathway (Castro et al., submitted; Pereira \& Martins-Lopes, 2015).

The aim of this study was to evaluate the capacity of HRM to access varietal identification in must and wine samples, in order to establish a future alternative authenticity procedure.

\section{Material and methods}

\subsection{Leaf, must and wine samples}

Thirteen $V$. vinifera varieties were selected based on their importance to the Portuguese wine sector, in particular to the Douro region. The sampling comprised national and international varieties (Table 1). Young leaf samples from each grapevine variety were harvested from certified vineyards (Sogrape Vinhos S.A. and Real Companhia Velha) and immediately frozen in liquid nitrogen until DNA extraction. Grape samples were harvested from the certified vineyards in two consecutive production years, 2012 and 2013. Monovarietal must and wine samples were produced at the National Institute for Agricultural and Veterinary Research (INIAV) in Dois Portos, Portugal, using freshly harvested grapes. All must samples were collected immediately after wine maceration and immediately frozen at $-20^{\circ} \mathrm{C}$. The wines were vinified using two procedures according to grape color.
Table 1

List of 13 grapevine varieties used, corresponding code and berry color.

\begin{tabular}{lll}
\hline Grapevine variety name & Code & Berry color \\
\hline Alicante Bouschet & AB & Red \\
Cabernet Sauvignon & CS & Red \\
Donzelinho Tinto & DT & Red \\
Merlot & M & Red \\
Malvasia Fina & MF & White \\
Pinot Noir & PN & Red \\
Rufete & Ruf & Red \\
Tinto Cão & TC & Red \\
Touriga Franca & TF & Red \\
Tinta Francisca & TFi & Red \\
Touriga Nacional & TN & Red \\
Tinta Roriz & TR & Red \\
Viosinho & Vio & White \\
\hline
\end{tabular}

\subsubsection{Vinification of white grape varieties}

White varieties grapes were weighed, crushed, destemmed and pressed separately. Immediately, $80 \mathrm{mg} / \mathrm{L}$ of sulfur dioxide $\left(\mathrm{SO}_{2}\right)$ was added to each must and then placed in a cold room at $4{ }^{\circ} \mathrm{C}$ for about $48 \mathrm{~h}$ for cold settling. After cold setting, the musts were transferred to two glass containers, in two equal parts for each variety, and the alcoholic fermentation was conducted by adding an active dry yeast (QA23) in the ratio of $30 \mathrm{~g} / \mathrm{hL}$ of must and $1 \mathrm{~g}$ of diammonium phosphate per $10 \mathrm{~L}$ of must. The must fermentation took place in a controlled temperature chamber $\left(16-18^{\circ} \mathrm{C}\right)$. At the end of alcoholic fermentation (reducing sugars $<3 \mathrm{~g} / \mathrm{L}$ ) the wines were racked and $40 \mathrm{mg} / \mathrm{L}$ of the $\mathrm{SO}_{2}$ was added. Approximately, 2 months after fermentation (December), the wines were transferred and the free $\mathrm{SO}_{2}$ levels were corrected up to $20 \mathrm{mg} / \mathrm{L}$. In January, all wines were sampled for further laboratory analysis, after which the free $\mathrm{SO}_{2}$ was fixed up to $40 \mathrm{mg} / \mathrm{L}$. Finally, the wines were bottled in $0.375 \mathrm{~L}$ glass bottles.

\subsubsection{Vinification of red grape varieties}

The red grape varieties were weighed, crushed and destemmed separately. Shortly after, $80 \mathrm{mg} / \mathrm{L}$ of $\mathrm{SO}_{2}$ and an active dry yeast (D254) was added in the ratio of $20 \mathrm{~g} / \mathrm{hL}$ of must. The musts were fermented in a controlled temperature chamber $\left(24-26^{\circ} \mathrm{C}\right)$. During this phase, the punch down of wine grapes was made twice a day. When the must density was lower than $1.0 \mathrm{~g} / \mathrm{cm}^{3}$, wine grapes pressing was made. The must/wine resulting was transferred into glass bottles to almost full capacity. When the fermentation ended, the operations performed were the same as described in white wines. Wine sampling was performed one year after bottling. When the bottle was opened, samples were taken and immediately frozen at $-20^{\circ} \mathrm{C}$ until the DNA extraction procedure was pursued.

\subsection{Genomic DNA extraction}

Total genomic DNA was extracted from frozen young leaf samples using the described CTAB method (Doyle \& Doyle, 1987). Must DNA extractions were performed using a modified CTAB protocol (Pereira et al., 2012). Wine genomic DNA extractions were performed according to the method described by Pereira et al. (2011). The DNA samples were diluted in $100 \mu \mathrm{L}$ of $0.1 \mathrm{X}$ TE buffer (Tris- $\mathrm{HCl} 100 \mathrm{mM}$, EDTA $0.1 \mathrm{mM} \mathrm{pH}=8$ ) to $10 \mathrm{ng} / \mu \mathrm{L}$ of working concentration. The determination of the samples' purity, integrity and quantity were based on measurements performed using a Nanodrop $^{\mathrm{TM}} 1000$ Spectrophotometer and by electrophoresis on a $0.8 \%$ agarose gel in $1 \mathrm{X}$ TAE buffer (Tris-acetate-EDTA).

\subsection{High-Resolution Melting assay design}

\subsubsection{HRM primer design}

The primer pairs tested for the HRM analysis are summarized in Table 2. The HRM primer pairs selected for the study were based on 
previous sequencing data described in Pereira and Martins-Lopes (2015) and Castro et al. (submitted). Three length fragments were tested in leaf, must and wine DNA samples (Table 2).

\subsubsection{PCR amplification and HRM analysis}

All PCR reactions were conducted in a 48-well plate using the StepOne Software v2.2.2 (Applied Biosystems, Foster City, CA, USA) in a $20 \mu \mathrm{L} /$ well total volume according manufacturing instructions. The final reaction mixture contained $20 \mathrm{ng}$ total DNA, $0.2 \mu \mathrm{M}$ forward and reverse primers, and $1 \times$ MeltDoctor HRM Master Mix (Applied Biosystems). The PCR amplification was followed by the HRM and included an initial denaturation step of $95{ }^{\circ} \mathrm{C}$ for $10 \mathrm{~min}$ followed by 40 cycles of $95^{\circ} \mathrm{C}$ for $30 \mathrm{~s}, 58-60{ }^{\circ} \mathrm{C}$ for $30 \mathrm{~s}$ and $72{ }^{\circ} \mathrm{C}$ for $30 \mathrm{~s}$, then a final extension step of $72{ }^{\circ} \mathrm{C}$ for $2 \mathrm{~min}$. The melting curve was obtained in continuous, performed as follow: $95^{\circ} \mathrm{C}$ for $30 \mathrm{~s}, 65^{\circ} \mathrm{C}$ for $1 \mathrm{~min}$ rising $0.3^{\circ} \mathrm{C} / \mathrm{s}, 95^{\circ} \mathrm{C}$ for $15 \mathrm{~s}$. During the incremental melting step, fluorescence data were continuously acquired. All reactions were performed in triplicate. High Resolution Melt Software v3.0.1 (Applied Biosystems, Foster City, CA, USA) was used to analyze the data. After normalization and the temperature shift determination, the different melting curves of the several plots were generated.

Several HRM assays were used. Assays $V v 1$ and $V v 2$ fragments were previously optimized using leaf samples (Castro et al., submitted; Pereira \& Martins-Lopes, 2015), while the $V v 3$ fragment was developed based on the sequencing information of the UDP-glucose: flavonoid 3-O-glucosyltransferase gene (UFGT) gene (Pereira \& Martins-Lopes, 2015).

\section{Results and discussion}

3.1. HRM analysis applied to must using Vv1 - 705 bp fragment (UFGT gene)

HRM analysis of a specific fragment belonging to the UFGT gene which allowed the identification of several grapevine varieties Pereira and Martins-Lopes (2015) was used. In the current study, the HRM assay was tested in must samples and compared to the leaf DNA reference material (Fig. 1). The HRM profile obtained between the two differentiated samples, leaf versus must, completely corresponded in all the grapevine varieties used (4 genotypes). These genotypes were selected based on the previous work once they produced different melting curve shapes (Pereira \& Martins-Lopes, 2015). The melting curve profiles were coincident with the previous ones obtained in leaf samples, demonstrating the robustness of the assay.

Even though it is well known that wine fermentation yields DNA highly degraded (Garcia-Beneytez, Moreno-Arribas, Borrego, Polo, \& Ibáñez, 2002), it is also true that must samples still contain high fragment genomic DNA, which enables it to be successfully used in marker systems that target large fragments, such as SSR markers (Baleiras-Couto \& Eiras-Dias, 2006; Bigliazzi et al. 2012; Pereira et al., 2012; Rodríguez-Plaza et al., 2006). The fragment size used in this assay is the biggest specific fragment reported so far in must samples, and it is interesting because it allows the discrimination of multiple events in one unique reaction, overcoming the potential obtained through SSR analysis which detects repeat variation.

Table 2

List of primers used in the HRM assays and the details of the amplified fragments.

\begin{tabular}{|c|c|c|c|c|c|}
\hline Fragment/gene & Primer sequence $\left(5^{\prime}-3^{\prime}\right)$ & Amplicon size (bp) & $\mathrm{Ta}\left({ }^{\circ} \mathrm{C}\right)$ & $\operatorname{Tm}\left({ }^{\circ} \mathrm{C}\right)$ & $\mathrm{N}^{\circ}$ and type of polymorphisms within Fragment \\
\hline Vv1/UFGT & $\begin{array}{l}\text { Fwd: GCAATGTAATATCAAGTCC } \\
\text { Rev: TTTCTTTCTTTGAGCCATT }\end{array}$ & 705 & 58 & $84.6-84.9$ & 32 SNPs and 1 INDEL \\
\hline Vv2/F3H & $\begin{array}{l}\text { Fwd: AGAGAAAGAAGGCGACGT } \\
\text { Rev: GATGGCTGGAAACGATGA }\end{array}$ & 375 & 58 & $84.6-84.9$ & 5 SNPs \\
\hline Vv3/UFGT & $\begin{array}{l}\text { Fwd: AGCAGAGATGGGGGTGGCTT } \\
\text { Rev: AGCAGGTAAAACCACCTGAA }\end{array}$ & 119 & 58 & $78.6-78.8$ and $81.7-81.9$ & 4 SNPs and 1 INDEL \\
\hline
\end{tabular}

Note: Ta - annealing temperature; Tm - melting temperature.

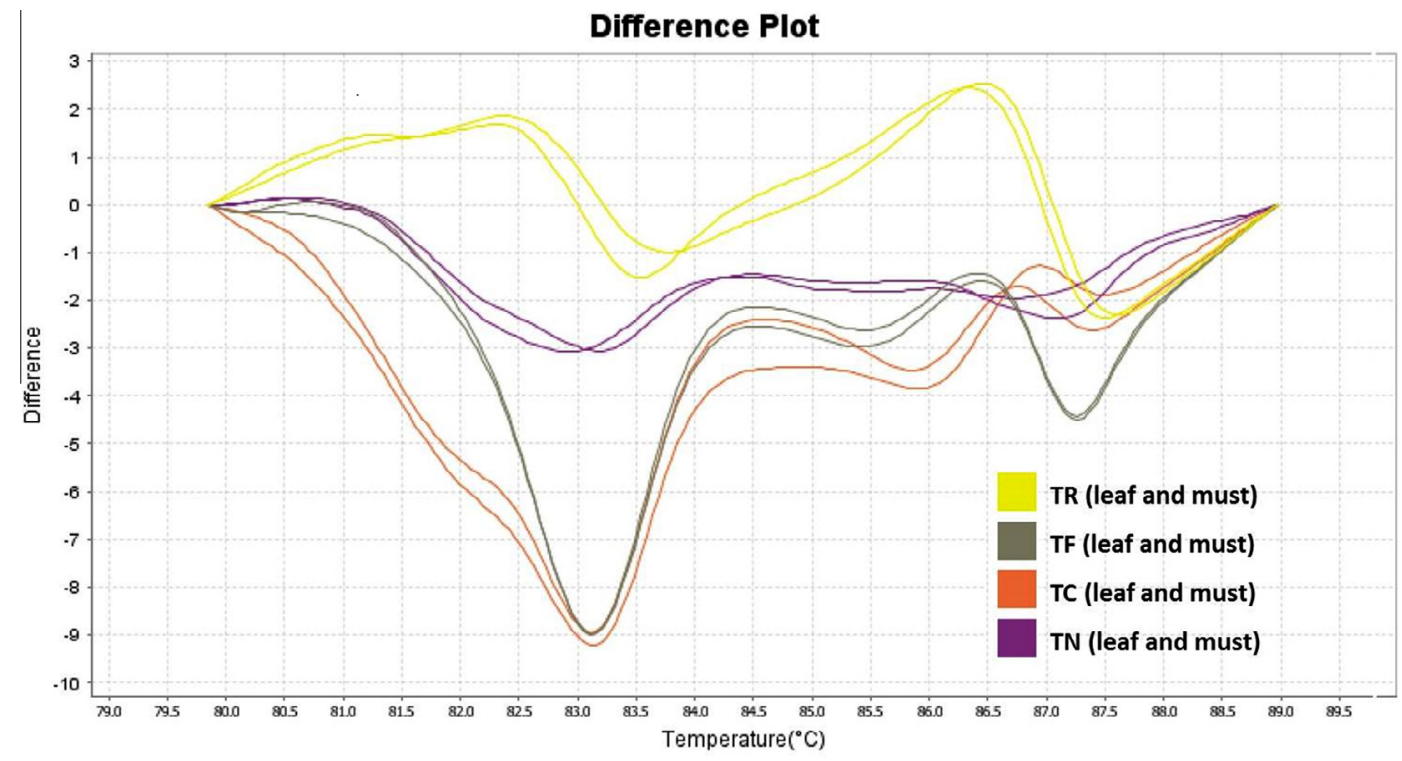

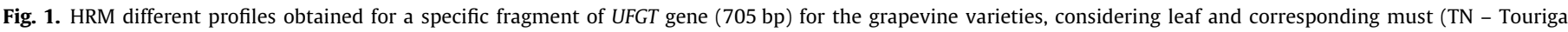
Nacional; TF - Touriga Franca; TR - Tinta Roriz; TC - Tinto Cão). 
When HRM assay was applied, as a screening method, to DNA extracted from wine samples no amplification was detected. This result was expected once the assay comprises a large fragment size that is not available after the wine fermentation procedures (Baleiras-Couto \& Eiras-Dias, 2006; Işçi, Yildirim, \& Altindişli, 2009). The developed HRM assay demonstrated that it is possible to apply HRM to: (i) large DNA fragments; (ii) fragments with a high number of SNPs; and (iii) must genomic DNA samples. In order to overcome constrains found in the wine DNA samples, two HRM assays were further tested using different fragment lengths.

\subsection{HRM analysis applied to must and wine using Vv2 - fragment 375 bp (F3H gene)}

The main drawback associated to wine authenticity is the nature of the DNA sample. The low quantity and the lack of integrity in wine DNA are associated with the fermentation process. Baleiras-Couto and Eiras-Dias (2006) reported that the identification of the grapevine varieties, in monovarietal wines, was not possible with nuclear markers. Several efforts have been conducted to create short fragments length markers targeting varietal identi- fication (Lijavetzky, Cabezas, Ibáñez, Rodríguez, \& MartínezZapater, 2007; Myles et al., 2010).

The HRM analysis is preferably applied to small fragment sizes (up to $300 \mathrm{bp}$ ) and with a low number of SNPs (Druml \& CichnaMarkl, 2014). Aiming to identify the grapevine varieties in monovarietal wines, an HRM assay with a smaller fragment $V v 2$ (375 bp) was used. The amplified fragment comprehended a total of five SNPs and was designed within the $F 3 H$ gene sequence (Castro et al., submitted).

The same group of grapevine varieties used in the first experiment was used and the international red grape variety Cabernet Sauvignon was added (Fig. 2A). A total correspondence was found between leaf and the correspondent must (Fig. 2A). These five varieties presented all the same sequence (Castro et al., submitted), and through the HRM assay it is evident that the exactly same profile is obtained in leaf and must samples (based on the melting temperature $-T_{m}$ ). When this HRM assay was applied to wine samples the exact same profile was found (Fig. 2B), demonstrating that although the fragment is still considerably big, it is possible to obtain amplification within wine samples when appropriated extraction methods are used.

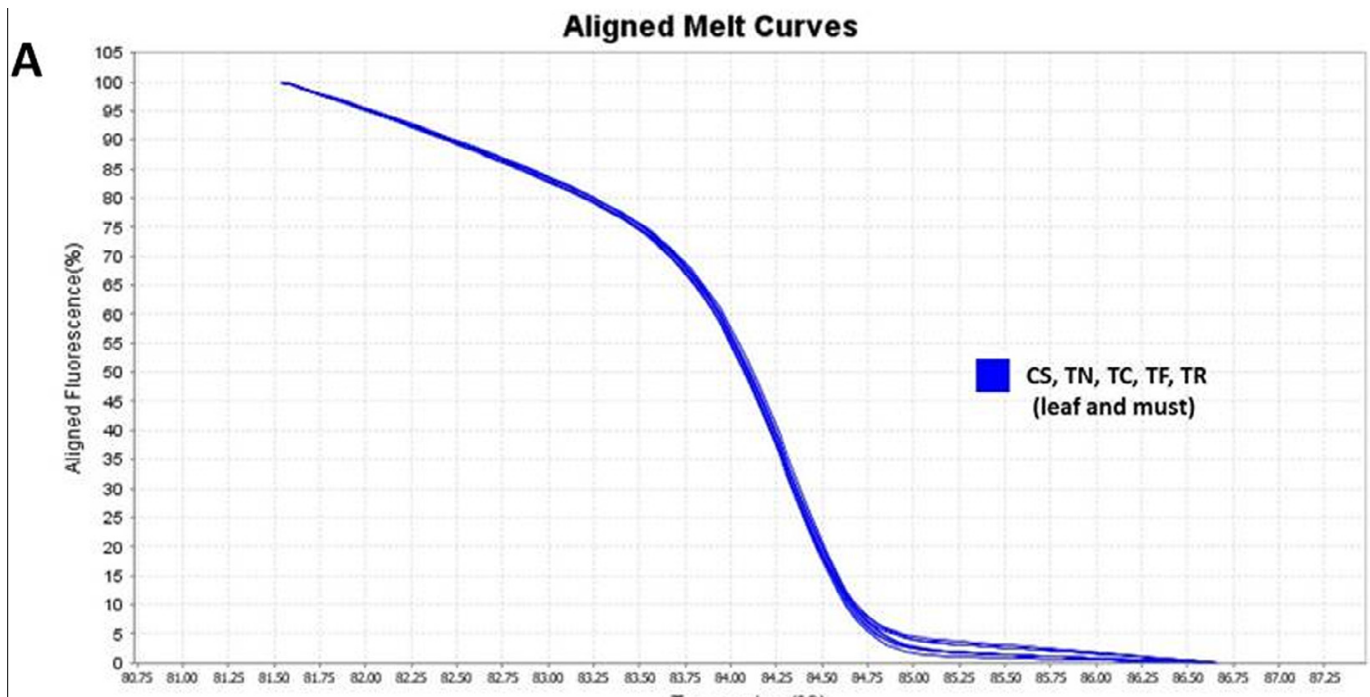

Aligned Melt Curves

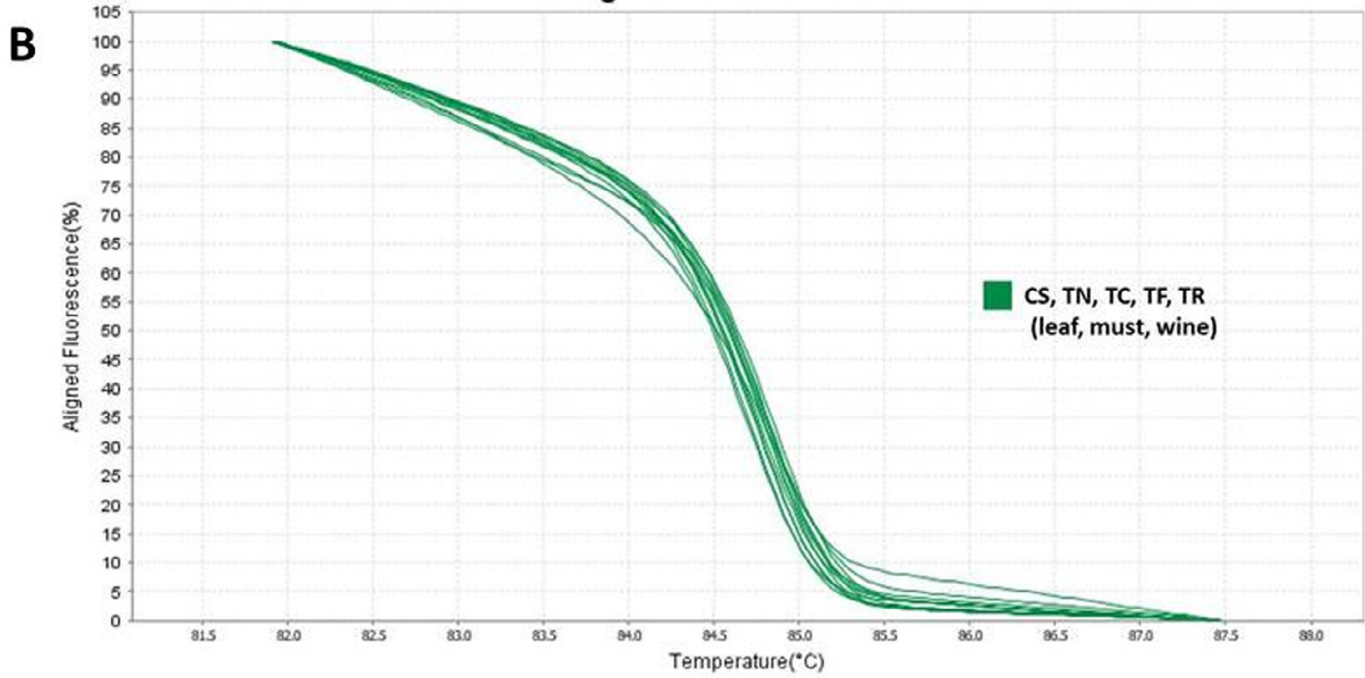

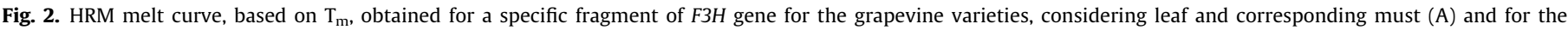
grapevine varieties, considering leaf and corresponding must and wine (B) (TN - Touriga Nacional; TF - Touriga Franca; TR - Tinta Roriz; TC - Tinto Cão). 


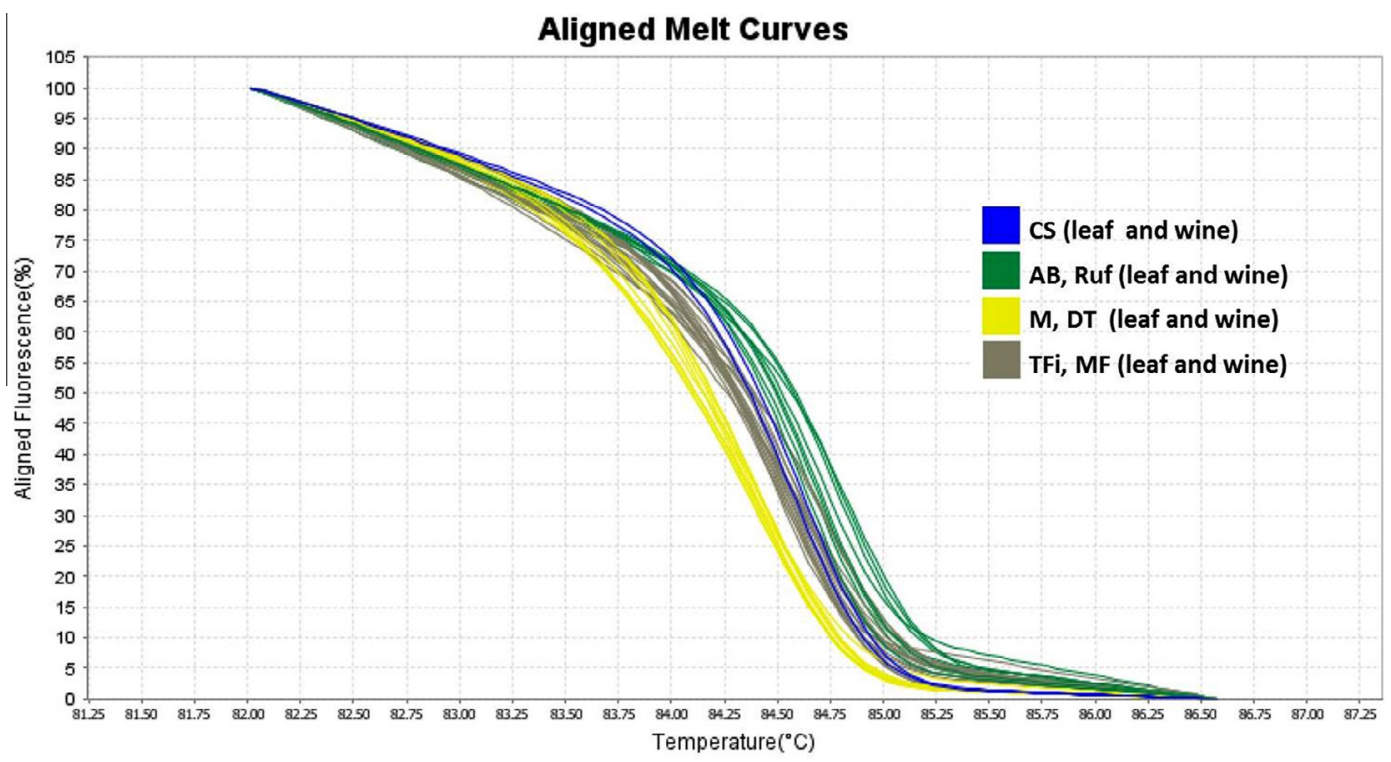

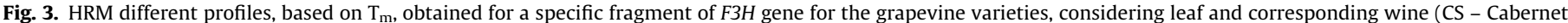
Sauvignon; AB - Alicante Bouschet; Ruf - Rufete; M - Merlot; DT - Donzelinho Tinto; TFi - Tinta Francisca; MF - Malvasia Fina).

In order to validate this HRM assay for wine authenticity purposes, a bigger number of grapevine varieties were included to discriminate the different genotypes, previously obtained through the sequencing analysis (Castro et al., submitted). In Fig. 3, four different genotypes, variants, were separated according to their $\mathrm{T}_{\mathrm{m}}$. The grapevine varieties were grouped according to their sequence, independent of their grape skin color, and the vinification process. Malvasia Fina is a white variety that was vinified with a different process and it did not interfere with amplification procedure. Not only the genomic DNA extracted from must and wine samples presented the required size for this particular assay but the DNA extraction procedures were efficient in the elimination of PCR-inhibitors (Pereira et al., 2011; Pereira et al., 2012).

HRM has been applied to fruit juice authenticity using the DNA barcode $\operatorname{trnL}$, allowing the discrimination of 5 species (Faria et al., 2013). The fragment used was around 500 bp long, however it is a chloroplastidial sequence, therefore it is less subjected to DNA fragmentation. The authors also refer in this study that DNA extractions needs to be optimized so PCR-inhibitors are not present.

\subsection{HRM analysis applied to wines using Vv3 - fragment $119 \mathrm{bp}$ (UFGT gene)}

In wine samples, the DNA amplicons length is an inherent disadvantage that influences the High Resolution Melting (HRM) sensitivity. With ageing the length of the DNA fragments, recovered from wine samples, are smaller, and therefore it is necessary to use shorter amplicon sequences for grapevine varietal identification (Baleiras-Couto \& Eiras-Dias, 2006). Thus, taking into consideration the known problematic, a new approach was developed based on a redesigning of the UFGT primer pair, using a smaller fragment, $V v 3$. This fragment is $119 \mathrm{bp}$ long, targeting short DNA fragments recovered in wine samples. The developed HRM assay generated 8 different HRM curve profiles, according to the grapevine varieties and wine samples' genotypes (Fig. 4A). A total of 8 genotypes were expected based on the sequencing information (Pereira \& Martins-Lopes, 2015). As depicted in Fig. 4A, 7 grapevine varieties (CS - Cabernet Sauvignon; VIO Viosinho; TR - Tinta Roriz; Ruf - Rufete; M - Merlot; AB - Alicante
Bouschet; and PN - Pinot Noir) were discriminated from the nine varieties studied. Two grape varieties, Touriga Nacional and Touriga Franca, presented the same melting curve shape, as expected, once they present the same sequence in the fragment under consideration. A coincident profile was obtained between the leaf, and wine DNA samples belonging to the same genotypes. In this case the discrimination of the haplotypes was based on the shape of the melting curves once the melting temperature $\left(T_{m}\right)$ values are similar between all samples. This analysis is more informative and allows a quick and visible accession of the genotypic differences found among grapevine varieties under study (Fig. 4A) than the one based only on $\mathrm{T}_{\mathrm{m}}$ results (Fig. 3 ). These results confirm that low-molecular weight markers based on small sequence differences are useful to detect grapevine DNA in wine samples, suggesting the possible application of HRM assay in grapevine varietal identification in DO wines and in undeclared admixture in wine.

In order to prove that this assay maybe used in commercial wines, a sample used in a previous study, "Torre de Ferro 2006" (Pereira et al., 2011), was tested (Fig. 4B). As shown in Fig. 4B one of the varieties present in the commercial wine "Torre de Ferro 2006", Tinta Roriz, amplified and presented the correspondent profile to the leaf sample of reference.

Similar approaches were considered when applying HRM to highly processed food samples. Vietina, Agrimonti, and Marmiroli (2013) reported on the use of a small amplicon, $71 \mathrm{bp}$, to detect alien oil in olive oil samples, using the $R b c 1$ chloroplast sequence.

HRM assay can be applied to complex food/wine matrices as long as several conditions are attended: (i) an efficient DNA extraction protocol is used taking into consideration the specific matrices characteristics; (ii) smaller DNA fragment are targeted and (iii) a combined number of single polymorphisms (SNPs) capable of differentiating several genotypes in one unique assay are used.

Within the developed HRM assays, based on MeltDoctor ${ }^{\mathrm{TM}}$, it was possible to have consistent and reproducible results independent of sample type (leaf, must and wine). This is interesting once the assay can be designed based on a set of primers, and it can be used to identify multiple events within a fragment, without the need of designing multiple probes to detect each genotype, as it is required when using TaqMan or Molecular Beacon technology (Madesis et al., 2014), hence decreasing the cost required per analysis. 


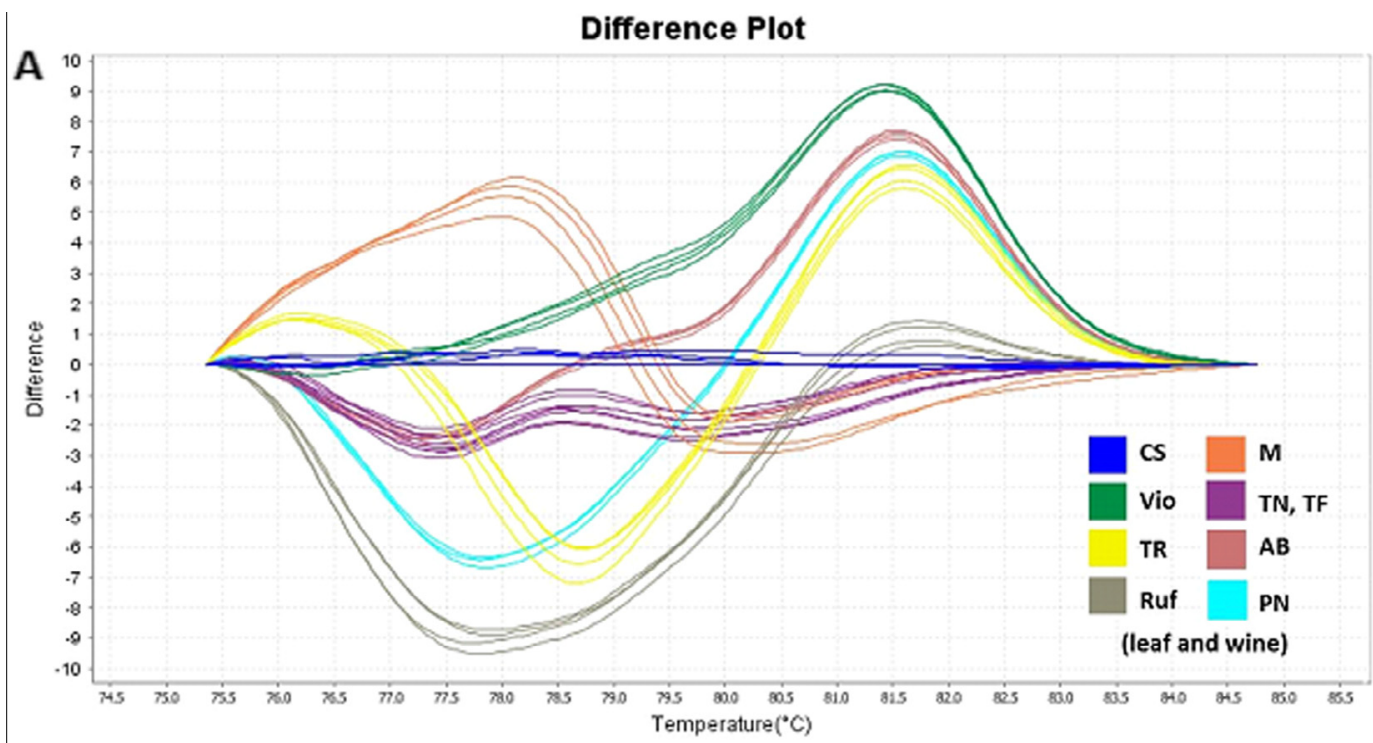

Difference Plot

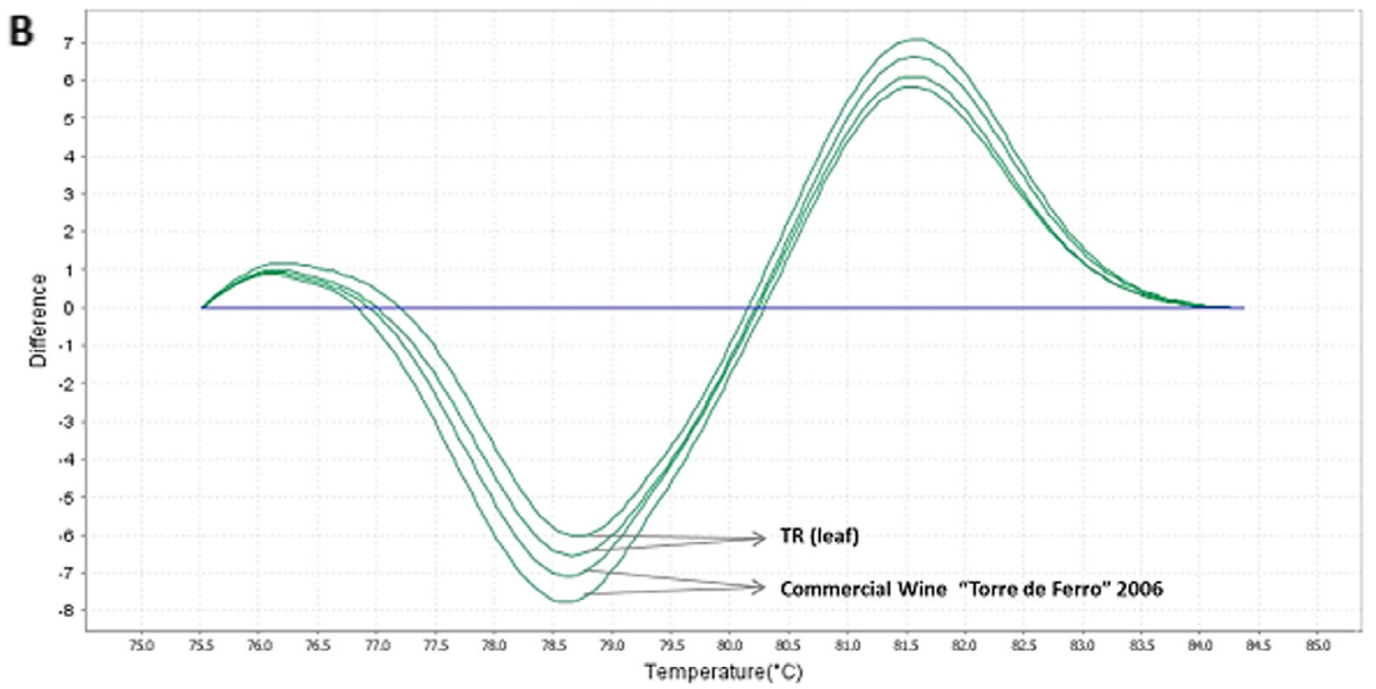

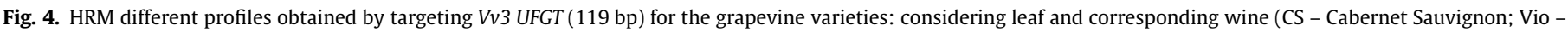

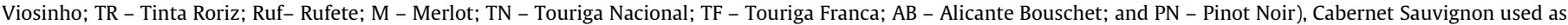

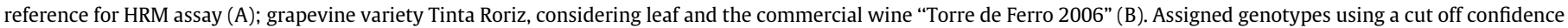
value of $95 \%$.

\section{Conclusions}

In the present work the use of HRM has proven to be successfully applied to must and wine controlled and commercial samples, opening new opportunities for the use of DNA-based methods for must and wine authenticity purposes. The use of smaller fragments, such as the one described for $V v 3$, guarantees a more robust and reliable method for wine authenticity, whereas for must samples higher fragments can be considered, increasing the discrimination power of the assay, once they are able to contemplate a higher number of SNP and INDEL events.

The application of HRM based assays in wine authenticity constitutes a consistent technology that can be cost effective, and therefore can revolutionize the wine sector, as long as a melt curve database is designed for such a purpose.

\section{Compliance with ethics requirements}

This study does not contain any studies with human or animal subjects.

\section{Conflict of interest}

None.

\section{Acknowledgements}

The authors are grateful to the Sogrape Vinhos S.A. and Real Companhia Velha, for letting us collect the samples in their fields. This research was supported by the Portuguese Foundation for Science and Technology (FCT) through the project Biosensor Development for Wine Traceability in the Douro Region - WineBioCode P TDC/AGR-ALI/117341/2010-FCOMP-01-0124-FEDER-019439, a PhD grant (SFRH/BD/44781/2008) and a Postdoctoral fellow (SFRH/BPD/70378/2010).

\section{References}

Arbulu, M., Sampedro, M. C., Gómez-Caballero, A., Goicolea, M. A., \& Barrio, R. J. (2015). Untargeted metabolomic analysis using liquid chromatography quadrupole time-of-flight mass spectrometry for non-volatile profiling of wines. Analytica Chimica Acta, 858, 32-41. 
Baleiras-Couto, M. M., \& Eiras-Dias, J. E. (2006). Detection and identification of grape varieties in must and wine using nuclear and chloroplast microsatellite markers. Analytica Chimica Acta, 563(1-2), 283-291.

Bigliazzi, J., Scali, M., Paolucci, E., Cresti, M., \& Vignani, R. (2012). DNA extracted with optimized protocols can be genotyped to reconstruct the varietal composition of monovarietal wines. American Journal of Enology E Viticulture, 63(4), 568-573.

Boccacci, P., Akkak, A., Marinoni, D. T., Gerbi, V., \& Schneider, A. (2012). Genetic traceability of Asti Spumante and Moscato d'Asti musts and wines using nuclear and chloroplast microsatellite markers. European Food Research and Technology, 235(3), 439-446.

Cabezas, J. A., Ibáñez, J., Lijavetzky, D., Vélez, D., Bravo, G., et al. (2011). A 48 SNP set for grapevine cultivar identification. BMC Plant Biology, 11, 153.

Camin, F., Bontempo, L., Perini, M., Tonon, A., Breas, O., Guillou, C., ... Gagliano, G. (2013). Control of wine vinegar authenticity through $\delta^{18} \mathrm{O}$ analysis. Food Control, 29, 107-111.

Castro, C., Gomes, S., Pereira, L., Jorge, P., Fernandes, J. R., \& Martins-Lopes, P. (submitted). SNP detection in F3H gene of Vitis vinifera L. for varietal identification using HRM and biosensors.

Cunha, J., Teixeira-Santos, M., Brazão, J., Fevereiro, P., \& Eiras-Dias, J. E. (2013). Portuguese Vitis vinifera L. germplasm: Accessing its diversity and strategies for conservation, the Mediterranean genetic code. In B. Sladonja (Ed.). Grapevine and olive. 978-953-51-1067-5. http://dx.doi.org/10.5772/52639.

Doyle, J. J., \& Doyle, J. L. (1987). A rapid DNA isolation procedure for small quantities of fresh leaf tissue. Phytochemistry Bulletin, 19, 11-15.

Druml, B., \& Cichna-Markl, M. (2014). High resolution melting (HRM) analysis of DNA - Its role and potential in food analysis. Food Chemistry, 158, 245-254.

Fang, F., Li, J. M., Zhang, P., Tang, K., Wang, W., Pan, Q. H., \& Huang, W. D. (2008). Food effects of grape variety, harvest date, fermentation vessel and wine ageing on flavonoid concentration in red wines. Food Research International, 41, 53-60.

Faria, M. A., Magalhães, A., Nunes, M. E., \& Oliveira, M. B. P. P. (2013). High resolution melting of trnL amplicons in fruit juices authentication. Food Control, 33, 136-141.

Ganopoulos, I., Argiriou, A., \& Tsaftaris, A. (2011a). Microsatellite high resolution melting (SSR-HRM) analysis for authenticity testing of protected designation of origin (PDO) sweet cherry products. Food Control, 22(3-4), 532-541.

Ganopoulos, I., Argiriou, A., \& Tsaftaris, A. (2011b). Adulterations in basmati rice detected quantitatively by combined use of microsatellite and fragrance typing with High Resolution Melting (HRM) analysis. Food Chemistry, 129(2), 652-659.

Ganopoulos, I., Bazakos, C., Madesis, P., Kalaitzis, P., \& Tsaftaris, A. (2013a). Barcode DNA High-Resolution Melting (Bar-HRM) analysis as a novel close-tubed and accurate tool for olive oil forensic use. Journal of the Science of Food and Agriculture, 93, 2281-2286.

Ganopoulos, I., Sakaridis, I., Argiriou, A., Madesis, P., \& Tsaftaris, A. (2013b). A novel closed-tube method based on High Resolution Melting (HRM) analysis for authenticity testing and quantitative detection in Greek PDO Feta cheese. Food Chemistry, 141, 835-840.

Garcia-Beneytez, E., Moreno-Arribas, M. V., Borrego, J., Polo, M. C., \& Ibáñez, J. (2002). Application of a DNA analysis method for the cultivar identification of grape musts and experimental and commercial wines of Vitis vinifera L. using microsatellite markers. Journal Agricultural and Food Chemistry, 50, 6090-6096.

Işçi, B., Yildirim, H. K., \& Altindişli, A. (2009). A review of the authentication of wine origin by molecular markers. Journal of the Institute of Brewing, 115(3), 259-264.

Isçi, B., Yildirim, H. K., \& Altindisli, A. (2014). Evaluation of methods for DNA extraction from must and wine. Journal of the Institute of Brewing, 120, 238-243.
Lijavetzky, D., Cabezas, J. A., Ibáñez, A., Rodríguez, V., \& Martínez-Zapater, J. M. (2007). High throughput SNP discovery and genotyping in grapevine (Vitis vinifera $\mathrm{L}$.) by combining a re-sequencing approach and SNPlex technology. BMC Genomics, 8, 424.

Mackay, J. F., Wright, C. D., \& Bonfiglioli, R. G. (2008). A new approach to varietal identification in plants by microsatellite high resolution melting analysis: Application to the verification of grapevine and olive cultivars. Plant Methods $4,8$.

Madesis, P., Ganopoulos, I., Sakaridis, I., Argiriou, A., \& Tsaftaris, A. (2014). Advances of DNA-based methods for tracing the botanical origin of food products. Food Research International, 60, 163-172.

Martins-Lopes, P., Gomes, S., Pereira, L., \& Guedes-Pinto, H. (2013). Molecular markers for food traceability. Food Technology and Biotechnology, 51, 198-207.

Myles, S., Chia, J. M., Hurwitz, B., Simon, C., Zhong, G. Y., Buckler, E., \& Ware, D. (2010). Rapid genomic characterization of the genus. Vitis. PLoS One, 5, e8219.

Nakamura, S., Haraguchi, K., Mitani, N., \& Ohtsubo, K. (2007). Novel preparation method of template DNAs from wine for PCR to differentiate grape (Vitis vinifera L.) cultivar. Journal of Agriculture and Food Chemistry, 55, 10388-10395.

Organisation Internationale de la Vigne et du Vin (OIV) (2007). 2nde edition de la liste des descripteurs OIV pour les variétés et espèces de vitis (p. 233). Paris: OIV.

Pereira, L., Gomes, S., \& Martins-Lopes, P. (2016). Nucleic acids sample preparation for food traceability. In Miodrag Micic \& Jeffrey D. Whyte (Eds.). Sample preparation of plant, animal and soil (Chapter 14. 1493931849, pp. 195-216). Springer Protocols Handbooks.

Pereira, L., Guedes-Pinto, H., \& Martins-Lopes, P. (2011). An enhanced method for Vitis vinifera L. DNA extraction from wines. American Journal of Enology and Viticulture, 62(4), 547-552.

Pereira, L., \& Martins-Lopes, P. (2015). Vitis vinifera L. single nucleotide polymorphism detection with High Resolution Melting analysis based on UDP-glucose: Flavonoid 3-O-glucosyltransferase gene. Journal of Agricultural and Food Chemistry, 3(41), 9165-9174.

Pereira, L., Martins-Lopes, P., Batista, C., Zanol, G. C., Clímaco, P., Brazão, J., ... Guedes-Pinto, H. (2012). Molecular markers for assessing must varietal origin. Food Analytical Methods, 5, 1252-1259.

Regulation (EC) No 607/2009. Official Journal of the European Union L 193 24.07.2009, p. 60.

Rodríguez-Plaza, P., González, R., Moreno-Arribas, M. V., Polo, M. C., Bravo, G., Martínez-Zapater, J. M., ... Cifuentes, A. (2006). Combining microsatellite markers and capillary gel electrophoresis with laser-induced fluorescence to identify the grape (Vitis vinifera) variety of musts. European Food Research Technology, 223, 625-631.

Savazzini, F., \& Martinelli, L. (2006). DNA analysis in wines: Development of methods for enhanced extraction and real-time polymerase chain reaction quantification. Analytica Chimica Acta, 563, 274-282.

Sen, I., \& Tokatli, F. (2014). Authenticity of wines made with economically important grape varieties grown in Anatolia by their phenolic profiles. Food Control, 46, 446-454.

Versari, A., Laurie, F. V., Ricci, A., Laghi, L., \& Parpinello, G. P. (2014). Progress in authentication, typification and traceability of grapes and wines by chemometric approaches. Food Research International, 60, 2-18.

Vietina, M., Agrimonti, C., \& Marmiroli, N. (2013). Detection of plant oil DNA using high resolution melting (HRM) post PCR analysis: A tool for disclosure of olive oil adulteration. Food Chemistry, 141, 3820-3826.

Wittwer, C. T. (2009). High-resolution DNA melting analysis: Advancements and limitations. Human Mutation, 30, 857-859. 